\title{
Correction: Correction: CD4 and Viral Load Dynamics in Antiretroviral-Naïve HIV- Infected Adults from Soweto, South Africa: A Prospective Cohort
}

\author{
The PLOS ONE Staff
}

There is an error in the fourth sentence of the Results section of the Abstract in the correction published on June 10, 2015. The correct sentence is: The overall mean decline in CD4 count was 3.2 cells $/ \mathrm{mm}^{3}$ per month. The publisher apologizes for the error.

\section{References}

1. Martinson NA, Gupte N, Msandiwa R, Moulton LH, Barnes GL, Ram M, et al. (2014) CD4 and Viral Load Dynamics in Antiretroviral-Naïve HIV-Infected Adults from Soweto, South Africa: A Prospective Cohort. PLoS ONE 9(5): e96369. doi: 10.1371/journal.pone.0096369 PMID: 24831447

2. Martinson NA, Gupte N, Msandiwa R, Moulton LH, Barnes GL, Ram M, et al. (2015) Correction: CD4 and Viral Load Dynamics in Antiretroviral-Naïve HIV-Infected Adults from Soweto, South Africa: A Prospective Cohort. PLoS ONE 10(6): e0130509. doi: 10.1371/journal.pone.0130509 PMID: 26061975

\section{OPEN ACCESS}

Citation: The PLOS ONE Staff (2015) Correction: Correction: CD4 and Viral Load Dynamics in Antiretroviral-Naïve HIV-Infected Adults from Soweto, South Africa: A Prospective Cohort. PLOS ONE 10(7): e0133093. doi:10.1371/journal.pone.0133093

Published: July 13, 2015

Copyright: @ 2015 The PLOS ONE Staff. This is an open access article distributed under the terms of the Creative Commons Attribution License, which permits unrestricted use, distribution, and reproduction in any medium, provided the original author and source are credited. 